\title{
O CAMPO DISCURSIVO DOS MINI-DOCUMENTÁRIOS SOBRE A CONDIÇÃO DIASPÓRICA NO CINEMA BRASILEIRO
}

\author{
Mahomed Bamba ${ }^{1}$
}

\begin{abstract}
Resumo: Num contexto histórico marcado por uma intensa discussão sobre a implementação de políticas afirmativas para com as populações afrodescendentes, assistimos, no campo cinematográfico e audiovisual brasileiro, a uma proliferação de filmes de curta e média metragem voltados para a representação dos diversos aspectos da identidade cultural "negra". Neste texto procuro entender como os diretores dos "curtadocs" etnicamente engajados revisitam uma temática recorrente na tradição do cinema brasileiro ("filmes de assuntos negros" do Cinema Novo) e também como eles renovam, esteticamente falando, os modos de figuração desta realidade, criando narrativas que transcendem a questão racial para configurarem-se em ensaios e discursos críticos sobre aquilo que chamo de "condição diaspórica" no Brasil. Sendo assim, parto da ideia de que são obras que inspiram uma série de hipóteses para repensar as categorias de "cinema negro" e "filmes diaspóricos" no interior do cinema brasileiro contemporâneo.

Palavras-Chave: Condição diaspórica; Curta-metragem; Documentário; Cinema brasileiro.
\end{abstract}

Resumé: À un moment où il est question de mettre en place des politiques affirmatives pour les populations "afrodescendants", l'on assiste, dans le champs cinématographique et audivisuel brésilien, à une prolifération de films de court et moyen métrage consacrés à la représentation des divers aspects de l'identité culturelle "noire". Dans ce texte, nous chercherons à comprendre comment les cinéastes des documentaires de court métrage ethniquement engagés revisitent une thématique déjà récurrente dans la tradition du cinéma brésilien (notamment dans les "films de sujets noirs" du Cinema Novo) et comment ils innovent, esthétiquement parlant, les modes de figuration de cette réalité, en créant des récits qui dépassent la question raciale pour se configurer en des essais et discours crítiques sur ce que je nomme ici "condition diasporique" au Brésil. Je pars donc de l'idée que ce sont des oeuvres qui inspirent une série d'hypothèses pour repenser les catégories de "cinéma noir" et de "filmes diasporiques" dans le cinéma brésilien contemporain.

Mots clé: Condition diasporique; Court métrage; Documentaire; Cinéma brésilien.

1 Professor Adjunto na Faculdade de Comunicação e pesquisador permanente, credenciado no Programa de Pós-Graduação em Comunicação e Cultura Contemporâneas da Universidade Federal da Bahia (Facom/PósCom/UFBA). Doutorado pela Escola de Comunicação e Arte da Universidade de São Paulo (ECA-USP). Endereço eletrônico: mahobam @hotmail.com. 


\section{INTRODUÇÃO}

A ideia de escrever este artigo remonta a uma experiência que tive com uma produtora catarinense, a Contraponto ${ }^{2}$, que tem como parceiros o portal CurtaDoc e a SESCTV. Em 2009, ela me submeteu três filmes de curta-metragem que formariam uma unidade para ser exibida na SESCTV na forma de um programa em três blocos. Eu tinha que ver os três curtas e "comentá-los" em poucas palavras. Não se tratava de fazer uma análise fílmica no sentido acadêmico do termo nem de empenhar-me numa exegese que esgotasse todos os sentidos dos filmes. Eu dispunha apenas do lapso de tempo de 3 a 5 minutos para tecer comentários sobre o contexto de produção dos filmes, o modo como cada diretor abordava a "temática negra" na sua narrativa documental. Em seguida, o programa foi ao ar com o título "A África é Aqui". Naquela altura, duas coisas chamaram a minha atenção: de um lado, a temática, "cultura afro-brasileira", que os produtores do "Contraponto" catarinense haviam escolhido para criar uma unidade discursiva com os três mini-documentários realizados em períodos diferentes; e, de outro, o rótulo com o qual o programa foi depois no ar, "África está Aqui". Na sinopse do programa se dizia: "Três documentários que abordam a cultura afro-brasileira: Aruanda, de Linduarte Noronha, realizado em 1960; Mata... Céu... e Negros, de Claudia Aguiyrre; e Som da Rua Dona Mercês, dirigido por Roberto Berliner". Se, por um lado, os três filmes reunidos configuram um corpus coerente quanto à temática, por outro, levantavam um desafio em termo de análise: que tipo de paralelo e correlações fazer entre a proposta estético-sociológica de Aruanda, um clássico na história do curta-metragem brasileiro, e as opções poéticas dos minidocumentários mais contemporâneos?

Desde então, perseguir fenômenos de continuidade (ou de ruptura) nas figurações da realidade das populações afrodescendentes em filmes de curta-metragem passou a fazer parte das minhas pequenas obsessões teóricas. Dessa primeira experiência nasceu, portanto, minha curiosidade e meu interesse em descobrir mais e mais mini-documentários contemporâneos que abordavam diversamente a temática da "cultura afro-brasileira". Depois me deparei com um enorme acervo de curtas disponíveis gratuita-

2 A Contraponto é uma produtora independente de conteúdo que realiza projetos audiovisuais com foco em arte, cultura, educação e meio ambiente. É especializada na produção de documentários e programas exibidos em emissoras de TV e distribuídos em DVD também. Tem sua base em Florianópolis e São Paulo.

58 Número temático: Literatura, cultura e memória negra. A Cor das Letras - UEFS, n. 12, 2011 
mente no Portal de CurtaDoc ${ }^{3}$. Depois de horas de visionamento de uma parte substancial desse material fílmico, fui descobrindo que, mais do que o tema da "cultura negro-africana", o que estava sendo representado e problematizado, de modo fragmentado e parcelar por cada curta, era a própria "condição diaspórica"" no Brasil. Neste lado do Atlântico negro, cada cineasta tenta apreender esta realidade histórica, civilizacional e existencial nas suas dimensões subjetiva (cinebiografias), intersubjetiva e comunitária (filmes sobre comunidades negras), histórica e memorial (curtas sobre quilombos e comunidades remanescentes de descendentes de escravos e suas memórias) etc. Este artigo é, portanto, o resultado de um primeiro esforço de sistematização das inquietações.

A seguir, começo discutindo os contornos genéricos e formais dos filmes de curta-metragem voltados para a representação da realidade afrobrasileira, procurando neles aquilo que Foucault chama de "fenômeno de série", isto é, a rede de unidades temáticas e enunciativas constitutivas de um campo discursivo particular no interior da longa tradição do curtametragem brasileiro. Em seguida, examino o protocolo de construção narrativa e poética próprio às obras de alguns diretores que vêm se destacando no interior desse campo por opções estéticas e estilísticas que situam seus trabalhos numa perspectiva autoral. $O$ texto parte de um movimento reflexivo que me leva do contato com filmes isolados em direção a obras de alguns diretores curta-metragistas (não todos!). No final desse movimento, chego à conclusão de que as relações afetivas, éticas e ideológicas de quaisquer cineastas com a mise-en-scène estratégica das experiências diaspóricas conduzem a uma redefinição dos conceitos de "cinema negro" e "cinema diaspórico" no campo do documentário em curta-metragem no Brasil.

3 http://www.curtadoc.tv/. Com a expansão dos espaços de recepção dos produtos cinematográficos e audiovisuais, os curta e média-metragem vêm adquirindo novas plataformas de exibição, o que tem facilitado seu acesso. É o caso dos portais "CurtaDoc-Uma Janela para o documentário" e Portacurta Petrobrás, além do Youtube, onde a maioria dos curtas metragens e alguns médias metragens são gratuitamente disponibilizados para visionamento. Os lançamentos de coletâneas de DVD completam essa circulação dos curtas, fora dos circuitos de festivais e de mostras. Uso o termo "diáspora" pensando nas diferentes acepções e sentidos que vem tendo através das definições de autores como Stuart Hall, Paul Gilroy, Edouard Glissant, entre outros. 


\section{CAMPO DOS FILMES DE CURTA-METRAGEM: ENTRE TRADIÇÃO, CONTINUIDADE E RUPTURA}

Segundo Foucault, o manejo de conceitos como descontinuidade, ruptura, fronteira, limite, série, transformações, na definição de um campo de saber ou formação discursiva, levanta questões de ordem metodológica que incluem um "trabalho negativo" no sentido de se livrar de algumas noções que acabam diversificando o tema da continuidade. Porém, como adverte Foucault, as noções, mesmo não tendo uma estrutura conceitual rigorosa, têm uma função clara, como é o caso da noção de "tradição", que, segundo Foucault, "visa a dar um estatuto temporal singular a um conjunto de fenômenos, ao mesmo tempo sucessivos e idênticos (ou análogos)" (FOUCAULT, 1969, p. 33). Seguindo a lógica do funcionamento da noção que é a tradição, é possível isolar casos de novidades que se perfilam por detrás da permanência, como é possível também "transferir o mérito das inovações para a originalidade, para o gênio e para a decisão própria dos indivíduos" (FOUCAULT, 1969, p. 34). É esse "jogo das noções" ${ }^{5}$ e de conceitos que encontramos na maioria dos estudos dedicados à compreensão da gênese da formação de alguns campos discursivos no cinema. Nas abordagens historiográficas e nos processos interpretativos, a noção de tradição serve para identificar unidades discursivas entre fenômenos aparentemente díspares e distantes no espaço e no tempo, mas serve também para apreender a lógica da diversificação e da continuidade que opera nos modos de representação fílmica de um determinado tema ou objeto. Por outro lado, as noções de obra, autores, textos, formas fílmicas etc. também intervieram na distinção de fenômenos de contiguidade e de ruptura entre diferentes práticas cinematográficas, períodos, escolas na história do cinema. Com a prática do curta-metragem, não podia ser diferente. Não somente os estudiosos postularam a existência de uma poética e uma forma fílmica particular nas narrativas dos curtas-metragens ${ }^{6}$ bem como lhes reconheceram uma evolução paralela no interior da história de algumas cinematografias nacionais ${ }^{7}$ ou regionais.

5 As noções de "influência", "desenvolvimento e evolução", "mentalidade", "tradição" etc.

6 Francis Vanoye e Anne Goliot-Lété (1994, p. 110), por exemplo, salientam no funcionamento das obras fílmicas curtas a tendência em exibir os dispositivos narrativos e discursivos, além de outras configurações retóricas "discerníveis" que Ihes são próprias. Estas observações valem tanto para os filmes de ficção como para os documentários. 
Se o documentário já é considerado como um "outro cinema" com sua própria história, os filmes documentários de curta/média-metragem são apreendidos até hoje a partir de certas "unidades discursivas" que os caracterizam no interior do campo da prática do documentário. Além do mais, muitos cineastas têm se dedicado exclusivamente ao curtametragem, enquanto outros veem nele uma passagem obrigatória para chegar ao longa-metragem em $35 \mathrm{~mm}$. Em todos os casos, os filmes de curta duração têm se tornado um meio de expressão experimental, mas, sobretudo, um meio de abordar fácil e diretamente as preocupações sociais e políticas.

A história do curta-metragem se articula também em torno de tradições, influências, fronteiras e passarelas (com o filme de longa-metragem, por exemplo). Alguns estudiosos, valendo-se da noção de influência, procuram casos de semelhança ou de repetição nos filmes de curta-metragem e de longa-metragem no interior da obra de um mesmo cineasta-autor ou dentro de uma geração de cineastas $^{8}$. No contexto brasileiro, J. C. Bernardet foi um dos primeiros estudiosos a se debruçar sobre a tradição do cinema de curta-metragem, reconhecendo na sua evolução períodos de classicismo e modernidade entre os anos 1960-1970:

Até os anos 50, o curta-metragem brasileiro, embora importante [...] e revelador de diversos aspectos da sociedade e da produção cinematográfica, não é um cinema crítico. É no decorrer da década de 50 e com os primeiros filmes de curta-metragem do Cinema novo que essa forma de cinema deixa de ser a sala de espera do longa-metragem ou a compensação de quem não consegue produções mais importantes (BERNARDET, 2003, p. 11).

Desde o início do livro Cineastas e imagens do povo, Bernardet explica que o seu objetivo nesse "ensaio" não é fazer uma "história", nem um "panorama" do cinema documentário. No entanto percebe-se no seu estudo a intervenção de alguns princípios foucaultianos, sobretudo quando ele abarca os diversos curtas-metragens estudados sob a rubrica de "gênero cinematográfico". O curta-metragem desponta como categoria fílmica sui generis no meio de outras "tendências ideológicas e estéticas" que, segundo Bernardet, procuravam, naquela altura da história cultural e cinematográfica do Brasil, fazer das artes uma forma de mediação na problematização da realidade social. Por trás da heterogeneidade das propostas poéticas

8 Cf. a importância do média-metragem Cabra marcado para morrer no conjunto da obra de Eduardo Coutinho e a relação dos cineastas da Nouvelle Vague com a prática do curtametragem antes da consagração do movimento. 
e estéticas do curta-metragem naqueles anos 50-60-70, Bernardet consegue, portanto, destacar uma "unidade discursiva" e uma estrutura temática que ele resume com a seguinte frase: "a maior parte da produção documentária evolui para o que se pode chamar de registro das tradições populares, da arquitetura, das artes plásticas, da música etc." (BERNARDET, 2003 , p. 12). Mas, dentro desse primeiro campo discursivo e temático dos curtas-metragens, Bernardet circunscreve mais um conjunto de obras peculiares que, além de se preocuparem com problemas sociais, são atravessadas de reflexividade metalinguística.

\section{ARUANDA E CONGO: DUAS OBRAS PRECURSORAS}

Com o passar do tempo, vem se desenhando, na história do cinema documentário brasileiro, uma filmografia sobre a temática negra ${ }^{9}$. É uma espécie de subcampo discursivo formado pelas imagens e narrativas de obras de curta-metragem, clássicas e contemporâneas, de cineastas que, numa perspectiva autoral, apropriaram-se da temática e a representam com uma liberdade de estilo e de tom. Aruanda (Linduarte Noronha, 1960) e Congo (Arthur Omar, 1972) são dois curtas-metragens que, além de se tornarem clássicos, ilustram, cada um, dois modos de apropriação cinematográfica da realidade diaspórica brasileira. Os estilos de mise-en-scène dos aspectos sociológicos e culturais desta realidade presentes nesses dois curtas se encontram em filigrana nas propostas narrativas de muitos minidocumentários contemporâneos brasileiros. Aruanda começa com letreiros que contextualizam a narrativa e insistem no valor do quilombo. A impressão que passa para o espectador é a de que o quilombo seria o tema central do documentário, sobre o modo de organização de uma população remanescente neste lugar carregado de simbolismo (população reduzida, aliás, à personagem e sua pequena família). Mas, na verdade, Noronha faz do quilombo um epifenômeno, uma espécie de pretexto para abordar a complexa ordem sócio-ecônomica do Nordeste e do Brasil. O filme narra um dos aspectos da história econômica do Nordeste canavieiro a partir do dia a dia dessa personagem e sua pequena família presos nesse ciclo econômico. Como diz bem este trecho do letreiro e da sinopse do filme, com o passar

9 No final de mês de novembro de 2003, ocorreu em São Paulo, no MIS, uma mostra de cinema com o seguinte título: Da chanchada à feijoada. O evento almejava destacar filmes brasileiros de curta e longa-metragem que representassem a "temática negra". 0 evento era também uma homenagem ao mês da Consciência Negra. 
do tempo, "Talhado transformou-se num quilombo pacífico, isolado das instituições do país, perdido nas lombadas do Chamadão nordestino, com uma pequena população presa a um ciclo econômico trágico e sem perspectiva, variando do plantio de algodão à cerâmica primitiva, vendida na feira ao pé da serra". Ao longo do filme, mesmo a realidade quilombola servindo de pano de fundo, essa temática passa a ser suplantada por uma preocupação "macro-econômica", isto é, Linduarte Noronha parte da realidade de um determinado quilombo situado no Sertão para falar de um dos aspectos da história econômica do Nordeste e do Brasil de forma geral.

Arthur Omar, no curta Congo, põe em cena a congada, uma manifestação cultural popular das comunidades afrobrasileiras dos estados de Minas Gerais e Espírito Santo. Mas opta por numa narrativa (ou desnarrativa) em que o experimentalismo, o formalismo estético e o jogo com os níveis do dito e da "mostração" acabam anulando as imagens congada no plano da representação ${ }^{10}$. Sobre o contexto de produção de Congo, Bernardet lembra o período de intensa produção de documentários em que se procurava "fixar os aspectos tradicionais da cultura de zonas rurais, sob o pretexto de promover a cultura popular, registrar a memória da nação ou documentar tradições que o avanço do capitalismo fazia desaparecer" (BERNARDET, 2003, p. 110). Porém, nesse contexto, Arthur Omar cria um paradoxo no seu curta-metragem ao tomar certa liberdade com relação a esta "missão": ao confiar a representação a elementos gráficos, aos letreiros e à voz off de uma criança, "Congo sonegando radicalmente seu referente, ou aparente referente ${ }^{11}$. Sendo assim, o curta fala indiretamente da congada ao invés de mostrá-la em imagens. Ao sonegar as imagens da congada, o filme também renuncia ou relega, aparentemente, num segundo plano as relações de uma determinada comunidade com essa festa popular de matriz africana. No entanto, mesmo com essas opções estéticas radicais em termos de representação, Congo não deixa de ter a condição diaspórica como objeto temático da sua não-narrativa. O filme levanta de forma enviesada muitas questões relacionadas a essa realidade cultural. Na falta de imagens "realistas" da congada, como frisa bem Bernardet na sua análise, os letreiros do filme "sugerem o universo cultural do cineasta, os critérios que ele leva em conta na composição do filme ou em sua reflexão sobre a congada". Se há, portanto, uma reflexão sobre esses aspectos da condição

\footnotetext{
${ }^{10} \mathrm{Cf}$ análise completa que J. C. Bernardet consagrou ao curta Congo no livro Cineastas e imagens do povo, 2003, p. 109-118.

11 Ibid, p. 110.
} 
diaspórica, ela é antes de tudo fruto de uma interpretação pessoal do próprio cineasta. Os contornos da série de curtas sobre a realidade dos afrodescendentes brasileiros começam a se desenhar com propostas narrativas autorais $^{12}$ de filmes como Aruanda e Congo. Esse subcampo discursivo, dentro da evolução do cinema documentário brasileiro, passa a ganhar certa unidade e nitidez com o aporte de outros curtas que abordam de forma naturalista, etnográfica ou experimental a mesma realidade diaspórica. Em alguns mini-documentários contemporâneos, nota-se, inclusive, uma atitude mais política e um desejo de levar a representação dessa temática pelos meandros de um cinema mais engajado social e etnicamente falando. Nesse caso, as formas de organização sócio-política das comunidades e populações afrobrasileiras interessam aos cineastas tanto quanto as suas práticas religiosas e culturais.

\section{MISE-EN-SCÈNE "AUTORAL" DA TRADIÇÃO ORAL E DAS MEMÓRIAS DAS COMUNIDADES AFRODESCENDENTES}

As inovações tecnológicas destes últimos anos permitem filmar em curta-metragem uma gama variada de questões sociais bem como dão uma nova atualidade a temáticas antigas que, mesmo recorrentes na história do cinema brasileiro, eram esporádica ou insuficientemente exploradas pelos primeiros cineastas em seus curtas ou longas-metragens ${ }^{13}$. Enquanto os discursos dos filmes do Cinema Novo retratavam a cultura e, sobretudo, a espiritualidade dos negros brasileiros pela perspectiva de um projeto de questionamento da identidade nacional, os mini-documentários contemporâneos abordam essas questões em si. Parto da hipótese de que o compromisso pessoal que alguns cineastas negros ou afrodescendentes têm com a temática negra os conduz a renovar o modo de representação das memórias das tradições culturais populares negras e de matriz africana no Brasil bem como os leva a produzir narrativas em que não hesitam em introduzir certa poesia em narrativas que constroem, geralmente, com uma consciência política e étnica afirmada. Interessam-se geralmente pelas histórias de vida de indivíduos, famílias ou personagens afrodescendentes

12 Origens e contornos que não precisam ser procurados só no conjunto de filmes etnográficos.

13 Há um paradoxo no fato de que, embora a história do documentário tenha começado no formato curta metragem, a problemática negra foi mais abordada nos filmes de longa metragem de ficção.

64 Número temático: Literatura, cultura e memória negra. A Cor das Letras - UEFS, n. 12, 2011 
comuns ou que se destacam de algum modo no meio das suas comunidades. O desejo de narratizivar e "documentarizar" a realidade das populações negras e afrodescendente toma, portanto, como objeto de discurso uma diversidade de questões. Por fim, são cineastas que procuram situar seus filmes nas antípodas do cinema etnográfico. Por isso, podemos dizer que eles fazem da "pesquisa etnográfica" um ponto de partida e não de chegada. Como este artigo não tem a pretensão de fazer considerações e comentários sobre todos os filmes que visionei no Portal Curta-docs, preferi escolher curtas cujas narrativas são ilustrativas e reveladoras da consciência autoral com que alguns cineastas afrodescendentes vêm se afirmando no cinema documentário brasileiro em curta-metragem. Seus minidocumentários surgem num contexto histórico ${ }^{14}$ em que há uma intensa discussão sobre a implementação de políticas afirmativas a favor das populações afrodescendentes, entre elas a lei sobre o ensino obrigatório da história e das culturas africanas nas escolas brasileiras. Sendo assim, procurei entender como alguns diretores curtametragistas (afrodescendentes ou não) participam desse debate público, revisitam novos e antigos "assuntos negros", mas também como, através de suas estratégias narrativas, abrem e estendem o tratamento dessas questões para uma problemática maior que chamei aqui de "condição diaspórica" no Brasil.

Já foi dito e repetido várias vezes: o documentário não se contenta em registrar ou representar mecanicamente a realidade. Cada cineasta procura, através da narrativa documentária, intervir sobre o "real" pelo modo interpretativo (inclusive nos documentários "observacionais"). A interpretação da realidade diaspórica na obra de Délcio Teobaldo, cineasta mineiro, começa por um minucioso trabalho de pesquisa de campo e termina com um exercício cuidadoso de mise-en-scène performática da cultura oral afro-brasileira. Em todos os seus curtas, Teobaldo (que é também jornalista, escritor) procura comunicar, de certa forma, ao espectador esse seu interesse pela pesquisa sobre o "profílmico". Aparecem sempre nos créditos de seus curtas as seguintes informações: "Pesquisa, roteiro e direção: Délcio Teobaldo". Ao se inspirar nas suas próprias histórias familiares, Délcio consegue misturar e entrecruzar dados biográficos e autobiográficos nas

14 É bom lembrar que as sucessivas "melhorias" da "Lei do Curta", dispositivo legal que regulamenta a exibição dos filmes brasileiros de curta-metragem, acabaram impactando positivamente também no polo da produção. O projeto Doc-Tv também contribuiu grandemente para a emergência desse contexto favorável à representação cinematográfica da "condição diaspórica" negra em média-metragem. 
narrativas que constrói sobre a prática cultural diaspórica do jongo. Para retratar o jongo, ele se vale das suas lembranças de criança, em seguida põe em cena as falas e as memórias de cinco pessoas de idade, depositárias dessa tradição oral. $\mathrm{O}$ documentário se transforma numa biografia dessas personagens, que seguem dando vida ao jongo, mas também traz à tona parte da relação afetiva do próprio diretor com o objeto de seu filme:

\begin{abstract}
$\mathrm{Na}$ verdade, minha literatura nada mais é que os contos ouvidos dos meus antepassados, contextualizados ao vivo; da mesma forma, meus três primeiros documentários, a trilogia "Morre Congo fica Congo, Ladainhas e Ofícios de Fé e de Cura e Cantos de Calamboteiros, remetem os olhares e a memória à minha avó Eva, negra senhora das candongas e caxambus; à minha avó Angelina, portuguesa católica apostólica romana, e à minha mãe, camponesa, benzedeira, bordadeira, atriz, cantadora, com quem conheci essas culturas por todas por dentro ${ }^{15}$.
\end{abstract}

São, portanto, os fragmentos dessa memória pessoal e familiar do próprio Délcio que servirão de matéria prima, além dos dados de pesquisa, para por em narrativa esta herança cultural que é o jongo. É também essa relação afetiva com o tema que dará um primeiro nível de unidade ao conjunto de sua obra (romances como filmes em curta-metragem). Em Morre Congo, fica Congo (2001), Délcio Teobaldo se interessa mais especificamente pelo jongo ou caxambu (preservado a custo de esforço) e pelas tribulações históricas das populações remanescentes de quilombos numa comunidade negra de Angra dos Reis. É a encenação das dimensões performáticas e coletivas dessa prática oral-rítmica que o filme busca privilegiar na sua narrativa. O mini-documentário de 15 min se abre com o plano fechado da imagem de uma lua cheia subindo de baixo para cima da tela. Fora do campo ouve-se o som de tambores e de cantos. A seguir, mais um plano fechado de uma fogueira numa noite escura. No terceiro segmento, aparecem pés de pessoas dançando numa roda, mas os dançarinos são mostrados de forma fragmentada: só os pés, as mãos, parte do tronco e a boca são exibidos em mais planos fechados.

Com esses três segmentos de abertura, o filme dá o tom e circunscreve metonimicamente o objeto de seu discurso - uma maneira de dizer que o retrato cinematográfico que ele dará do jongo privilegiará seus componentes estruturais, que são os pontos falados, cantados e as palmas das mãos dos dançarinos. Mas, depois dessa abertura, numa reviravolta, o filme

${ }^{15}$ Cf entrevista em: http://tvgeracaodigital.wordpress.com/2009/12/14/pivetim-delcioteobaldo/.

66 Número temático: Literatura, cultura e memória negra. A Cor das Letras - UEFS, n. 12, 2011 
introduz outro segmento com um discurso mais político sobre o passado e a dura realidade social da comunidade negra que mora num morro. Um letreiro atravessa a tela de ponta a ponta com a seguinte menção: "1973, ditadura militar brasileira, governo General Emílio Garrastazu Médici". Em seguida, uma voz over destila outras informações para contextualizar e situar a história dessa comunidade e de tantas outras onde se pratica ainda a duras penas o jongo com muito esforço. $O$ espectador passa a saber então que famílias inteiras foram expulsas de zonas rurais e migraram para a cidade; ficaram relegadas nos morros que "crescem como terra de ninguém". É nesses bolsões e nessas novas "diásporas urbanas" que o jongo rural revela todo o seu valor comunitário e de coesão social entre as populações majoritariamente afrodescendentes nesses morros afastados de Angra dos Reis.

Depois desse segmento de contextualização, o filme volta ao jongo, deixando falar cinco velhos guardiões e mestres dessa prática oral. A partir daí, Morre Congo, fica Congo começa a se apresentar ao espectador em três partes com os seguintes títulos: Terra - Jongo - Ponto. Em cada parte, os depoentes fazem comentários sobre a situação topográfica e agrícola da região, sobre o valor e a importância sócio-cultural do jongo para a comunidade ("jongo é alegria"; "veio do cativo com os escravos"). Eles explicam também o sentido das letras dos cantos (alguns remetem à origem diaspórica: "Vim de Angola, vou para Angola"). A narrativa dos dois outros curtas que compõem esse tríptico ${ }^{16}$ segue a mesma démarche. Délcio faz mais do que registrar uma variante dessa manifestação cultural afrobrasileira presente na maioria da região Sudeste do Brasil. Na verdade, ele parte do registro da prática do jongo para problematizar alguns aspectos sócioculturais da condição diaspórica, nos dias de hoje, naquela comunidade específica de Angra dos Reis que vive com suas memórias. Pelo menos a maneira como estrutura sua narrativa permite aferir tal hipótese.

\section{EU TENHO A PALAVRA OU A ENCENAÇÃO DO IMAGINÁRIO LINGUÍS- TICO DOS AFRODESCENDENTES}

Encontramos essa estratégia de colocação em discurso das diversas facetas da vida das comunidades afro-brasileiras nas obras de outros diretores. Geralmente eles retratam alguns indivíduos marcantes nessas comu-

16 Os três curtas, se forem postos juntos, teriam uma duração de 69 minutos e passariam a formar, assim, um filme longa-metragem. 
nidades, dando-lhes uma dimensão metonímica, isto é, através de uma cinebiografia, conseguem abraçar questões diaspóricas mais gerais. Esse princípio de construção narrativa é nítido na obra da Lilian Solá Santiago. Com um filme de média-metragem (Família Alcântara, 2005) e alguns curtas, essa cineasta de São Paulo vem se consagrando como um dos grandes nomes do cinema documentário negro (ou daspórico) brasileiro. No curta Eu tenho a palavra (26 min, 2010), ela aborda a questão do componente africano da cultura brasileira pela perspectiva dos modos de sobrevivência e de recriação da língua bantu entre os descendentes de africanos escravizados no Brasil. Por meio dessa "viagem linguística", Lilian transporta o espectador ao cerne da realidade diaspórica, onde os imaginários africanos e afrobrasileiros continuam em sincronia por além-mar. Através da encenação desse imaginário linguístico, o documentário procura também reencontrar esse elo entre os dois lados do Atlântico negro. O curta toma o cuidado de preparar e balizar os caminhos dessa longa viagem pela história das línguas das populações diaspóricas por informações preliminares e por longos trechos de textos explicativos. Depois dessa introdução didádica, Lilian deixa o curta "aos cuidados" de duas personagens que vão conduzindo a narrativa com seus depoimentos. Essa dupla de personagens é formada por uma senhora negra e um jovem angolano que mora no Brasil. É com eles que o espectador vai perambulando numa paisagem bucólica e linguística, entre cantos e reflexões sobre a capacidade de preservação das línguas de origem africana. Se há um ponto comum entre o média-metragem Família Alcântara e o curta Eu tenho a palavra, é justamente na repetição desse princípio de olhares cruzados sobre a experiência africana e diaspórica: nos dois documentários, intervém sempre uma personagem africana ${ }^{17}$ que faz considerações sobre a capacidade de as populações afrodescendentes preservarem algo que, às vezes, perdeu-se na própria África. Além da questão linguística, como podemos ver, neste caso, a preocupação com a "condição diaspórica" é representada não só pelo diálogo real e imaginário entre os afrodescendentes e a África mas também pela compreensão mútua entre Amadeus Fonseca (o angolano) e a senhora negra quando ambos começam a falar e repetir algumas palavras e expressões em quimbundo. Ao afirmar que esse curta era mais um passo a mais na sua "pesquisa pessoal traduzida em projetos audiovisuais sobre a cultura afro-brasileira", a cineasta Lilian Solá deixa claro seu empenho em querer conciliar preocupações de ordem

17 Em Família Alcântara, trata-se de um padre congolês que vive em Minas Gerais e que conhece bem os membros da família Alcântara.

68 Número temático: Literatura, cultura e memória negra. A Cor das Letras - UEFS, n. 12, 2011 
ética e estética no seu trabalho com cineasta "autora". Isso se nota no plano da obra. O estetismo da fotografia nos primeiros planos do filme, os cuidados e o esmero nos enquadramentos e na captação de som direto (som ambiente), bem como a trilha sonora confirma esta vontade de produzir um efeito geral "agradável" para o espectador em termos de experiência estético.

Encontramos essa mesma preocupação estética nos filmes de curtametragem de um cineasta ferrenho defensor do cinema negro que, antes de passar para o cinema de longa-metragem de ficção, começou a expressar suas inquietações com a realidade afrobrasileira no registro de curtametragem: Jeferson De. Desde o manifesto "Dogma Feijoada", Jeferson vem se afirmando não só como um dos principais cineastas negros contemporâneos, com maior visibilidade com Joel Zito, mas também como um cineasta que deixa claramente legível e visível uma nítida consciência autoral no conjunto da sua obra, que, globalmente, gira em torno de retrato de personagens negras. A cinebiografia é o gênero mais visitado por Jeferson nos seus filmes de curta-metragem. Às vezes com um toque de esteticismo e de poesia, consegue trazer à luz personagens negras famosas (mas esquecidas) ou anônimas, dando uma segunda visibilidade.

\section{CAROLINA (2003): OU A MISE-EN-SCÈNE DO DIÁRIO DE UMA FAVELA- DA E DESCENDENTE DE ESCRAVOS}

Em Carolina, curta metragem de 10 min., Jeferson De faz um retrato póstumo de uma mulher negra com uma trajetória de vida atípica. Ela morou numa favela com sua filha; foi escritora e teve um reconhecimento internacional, mas acabou morrendo no esquecimento. 0 curta ${ }^{18}$ é, portanto, uma espécie de exercício de resgate da memória de Carolina Maria de Jesus, razão pela qual as imagens de arquivo desempenham uma função primordial nesse filme. $O$ filme começa com algumas imagens de arquivo que mostram o funeral da Carolina (deitada no caixão). Elas são completadas por imagens da pequena dramatização protagonizada pela atriz Zezé Mota, que representa a personagem de Carolina nesse docu-ficção (junto com uma criança que representa a filha de Carolina). O trabalho de reconstituição da memória de Carolina é quase todo baseado no seu próprio diário. $\mathrm{O}$

\footnotetext{
18 Ver o roteiro de Carolina e de outros curtas de Jeferson De, bem como seus comentários sobre seu processo de criação no livro Dogma Feijoada e o cinema Negro Brasileiro. São Paulo: Impressa Oficial, 2005.
} 
conteúdo do diário é literalmente transposto na tela pela voz de Zezé, que é o tempo todo mostrada em planos médios e planos fechados, escrevendo ao mesmo tempo em que lê de forma cadenciada cada palavra e frase.

A importância do diário na estrutura deste curta-metragem lhe confere os aspectos de uma cinebiografia, ao mesmo tempo em que realça suas dimensões intimista e subjetiva. Por outro lado, essa opção de mise en scène faz da própria Carolina Maria de Jesus a narradora na primeira pessoa. Quando Zezé Mota declama cada palavra e frase antes de escrever no diário, é Carolina que o espectador ouve falar da sua própria experiência de vida. Ao deixar ecoar a voz de Carolina através da leitura de seus escritos, o documentário permite também um acesso direto à sua consciência de sujeito. Seu diário é constituído como um discurso sobre a realidade social circundante. São pequenas reflexões a respeito das relações inter-raciais, dos conflitos e das atribulações que configuram o dia a dia de pessoas simples num país multiético como o Brasil. Às vezes ela se refere ao racismo e ao preconceito ambientes mediante anedotas aparentemente anódinas. As imagens de arquivos que compõem o resto da iconografia dessa biografia transformam, portanto, o filme num dever de memória: trazer Carolina do limbo do esquecimento e the restituir uma dignidade e o devido reconhecimento. Alguns intertítulos aparecem intercalados na estrutura do filme e trazem informações adicionais ao espectador nesse sentido. As letras da trilha sonora dos créditos finais (canção "Negro drama" dos Racionais MC's) estão presentes para dizer que a história de Carolina contada nesse filme de curta-metragem é mais do que uma biografia de uma favelada: é parte da realidade de milhões de afrodescendentes no Brasil.

Os três filmes que comentamos até aqui têm em comum o fato de serem curtas realizados por cineastas afrodescendentes que declaram um compromisso quase ético e político com a questão da representação da temática étnico-racial. Mas, por outro lado, Délcio Teobaldo, Solá Santiago e Jeferson De constroem suas respectivas obras numa lógica que podemos considerar como "autoral". Dito de outra maneira, todos abordam o mesmo tema, mas tentam apropriar-se dele em diversas abordagens cinematográficas e estilísticas que marquem suas relações particulares com esta realidade. Isso faz emergir, no conjunto formado pelos curtas de cineastas afrodescentes, personalidades com estilos próprios e oferece narrativas em que a consciência de engajamento político se completa por uma preocupação com o trabalho de mise en scène. 


\section{DO “FILME DE ASSUNTO NEGRO" AO FILME SOBRE AS MEMÓRIAS E EXPERIÊNCIAS DIASPÓRICAS NO BRASIL}

Se tentarmos situar as obras de todos os cineastas curtametragistas numa espécie de história das ideias (ou história das imagens e das narrativas fílmicas), logo nos deparamos com o problema da qualificação ou definição correta da realidade que transparece em filigrana na maioria dos filmes brasileiros. A temática negra e da negritude se apresenta como uma "unidade de objeto" pré-existente e cuja representação vem sendo negociada diferentemente na obra dos cineastas de ontem e de hoje. Ao longo de todas as fases de evolução do cinema brasileiro, existe, entre todos os cineastas, uma espécie de uma consciência difusa e compartilhada com relação às memórias e à história das populações afrodescendentes. A figuração dessa realidade "étnico-racial" deu lugar a duas categorias de filme e de cinema que o cineasta e crítico Davis Neves rotulou como "filmes negros". Mas Neves toma o cuidado de distinguir o "cinema de assunto negro" do "cinema de autor negro":

O filme de autor negro é fenômeno desconhecido no panorama cinematográfico brasileiro, o que não acontece absolutamente com o filme de assunto negro, que, na verdade, é quase sempre uma constante, quando não é um vício ou uma saída inevitável. A mentalidade brasileira a respeito do filme de assunto negro apresenta ramificações interessantes tanto no sentido da produção e de realização quanto do lado do público ${ }^{19}$ (NEVES, 1968, p. 75).

É bom lembrar que essas tentativas de definição e de conceituação do cinema feito em torno do "assunto negro" tomaram como base de reflexão alguns filmes do Cinema Novo, sobretudo nos filmes de Carlos Diegues, Nelson Pereira dos Santos e Glauber Rocha ${ }^{20}$. Desde então, o debate sobre a afirmação de um cinema negro no Brasil também tem se focado demasiadamente na produção fílmica de longa metragem, em $35 \mathrm{~mm}$ e nos filmes de ficção. Para muitos, a emergência de um cinema negro começaria pelo

19 A expressão "O cinema de assunto e autor negros no Brasil" é o título de uma comunicação apresentada pelo cineasta e crítico David Neves na V Resenha do Cinema LatinoAmericano, em 1965, citado por Noel Santos Carvalho em seu texto "Esboço para uma História do Negro no Cinema Brasileiro". Em Jeferson De, Jeferson De: dogma Feijoada e o cinema Negro Brasileiro. São Paulo: Impressa Oficial, 2005, p. 68-69.

20 Cf Noel Carvalho, "Racismo e anti-racismo no Cinema novo". In: Esther Hambúrguer; Tunico Amâncio et alii, Estudo de Cinema, Socine, São Paulo: Annablume, 2008, p. 53-60. 
questionamento da "invisibilidade" ${ }^{21}$ e da subalternidade do negro nas telas. Consequentemente, há uma justa reivindicação de uma maior presença de atores e atrizes negros nas ficções cinematográficas e audiovisuais no Brasil. Mas, paradoxalmente, a produção cinematográfica documentária e em curta metragem não está merecendo a mesma atenção dos pesquisadores nos seus estudos sobre essa problemática de déficit de representação étnica. Ora, há, entre os novos cineastas de filmes de curta-metragem, uma vontade de levar a prática de "filme de assunto negro" para além da dimensão racialista que esse rótulo pode conotar. Cada diretor, negro ou branco, parece empenhado na construção de um discurso fílmico que concerne à própria "condição diaspórica", isto é, à condição que abarca os modos de auto-afirmação e de organização sócio-cultural e espiritual dos afrodescendentes ao longo da história do Brasil. É como se alguns curtas quisessem mergulhar no hic et nunc dessa realidade negro-africana no Brasil. Há um fenômeno de multiplicação de enfoques, mas também de pulverização das questões. Se há, portanto, um paralelo a ser feito (em termos de influência, continuidade ou ruptura) entre as propostas dos cineastas contemporâneos e os da era do cinema novo, por exemplo, sem dúvida, deve ser pensado em termos de continuidade e procurado nessa reconfiguração e requalificação do objeto da representação.

Muitos diretores contemporâneos de filmes de curta-metragem, mesmo sem recorrer ao radicalismo formal de Arthur Omar, em Congo, passaram também a construir tipos mais brandos de "ensaios" e de discursos sobre as memórias diaspóricas e sobre o lugar das identidades negras na identidade nacional brasileira ${ }^{22}$. Em alguns casos, a realidade das populações afro-brasileiras é abordada na perspectiva de projetos cinematográficos política e socialmente engajados e com objetivos pedagógicos ${ }^{23}$. $\mathrm{Na}$ categoria de mini-ducumentários interessados nas memórias das comuni-

21 Cf O Negro Brasileiro e o Cinema (2001), de João Carlos Rodrigues, e o documentário $A$ Negação do Brasil (2000) e o livro A negação do Negro: o negro na telenovela brasileira (Ed. SENAC, 2004), de Joel Zito de Araújo.

22 Numa entrevista, o cineasta Joel Zito, considerado como uma das principais figuras do cinema negro Brasileiro da atualidade, explica que mesmo "a estética e a dramaturgia negras" fazendo parte dos objetos de sua filmografia, sentia-se cada vez mais livre e solto na escolha de aspectos da realidade brasileira a serem figurados. Essa démarche ensaística é recorrente na maioria dos documentários de média-metragem do projeto DocTV.

Enquadro Negros (2003) é um documentário composto de cinco curtas-metragens, resultado de um projeto conduzido pelo diretor cineasta Luiz Antonio Pilar e que visa a dar visibilidade às produções fílmicas de jovens cineastas negros.

72 Número temático: Literatura, cultura e memória negra. A Cor das Letras - UEFS, n. 12, 2011 
dades afrodescendentes, o quilombo se tornou, novamente, um tema central e diversamente revisitado pelos diretores curtametragistas, a ponto de criar uma espécie de sub-categoria à parte. Esse número crescente de curtas sobre a realidade dos quilombolas tem a ver com a maior conscientização do valor simbólico e histórico desses redutos históricos de resistência contra a escravidão, mas também tem a ver com a conjuntura política atual do Brasil, em que há um intenso debate (e polêmica) sobre a implementação de políticas afirmativas no Brasil $^{24}$ para todos os grupos étnicos. Ao mesmo tempo em que se elaboram leis que visam ao ensino obrigatório da história e das culturas africanas nas escolas brasileiras, por outro lado há um esforço para uma maior valorização da contribuição das culturas das populações negras e afrodescendentes na identidade brasileira. Por exemplo, o mini-doc Mata... Céu... Negros (2005), da cineasta catarinense, Claudia Aguiyrre, é um projeto cinematográfico concretizado graças ao Prêmio Revelando os Brasis I (do MinC/Secretaria do Audiovisual). Nesse curta, a diretora catarinense recorre à técnica da entrevista para colher os depoimentos e testemunhos de descendentes de escravos na região do município de Antônio Carlos-SC. Em sua sinopse, o objetivo do mini-documentário é claro: "resgatar parte da memória dos poucos descendentes negros da região de Antônio Carlos, localidade próxima a Florianópolis, ainda segregados em algumas comunidades do município e que em outros tempos constituíram a maioria da população, quando as fazendas locais produziam com mão de obra escrava". Como podemos ver, o interesse pode recair tanto nos quilombos demarcados e reconhecidos como tais bem como pode se focar nas histórias de homens e mulheres que continuam dando vida a esses quilombos modernos espalhados pelo Brasil afora. Pensar o conjunto da produção fílmica em curta-metragem em termos de campo de discursos sobre a "condição diaspórica" permite, entre outras coisas, repensar a importância, o papel e o estatuto do discurso de outros realizadores que, mesmo não sendo afrodescendentes ${ }^{25}$, dedicaram-se ou continuam se dedicando à representação da realidade sócio-cultural negra no Brasil nas suas obras fílmicas.

${ }^{24}$ O lançamento da edição especial de um DVD do documentário Família Alcântara, por exemplo, foi programado para que coincidisse com a data comemorativa do dia da Consciência Negra em 2006.

25 No portal do CurtaDoc, alguns documentários são classificados sob o tag e o tema de "afrodescendente". 


\section{NOÇÃO DE “FILME DIASPÓRICO”}

Podemos, portanto, definir a condição diaspórica como um conjunto de comportamentos, experiências e práticas sócio-culturais e artísticas que revelam as lógicas e contradições que intervêm nas encenações dessas memórias de origem africana na história e na modernidade de alguns países que compõem a "Neo-América". São os aspectos desse processo de reinvenção sócio-cultural, de "sobrevivências" e de lutas pelo reconhecimento no contexto de um determinado estado-nação que muitos filmes acabam por representar de uma forma direta ou indireta. Ao longo da evolução do cinema brasileiro, a memória da escravidão, as formas de organização sócio-cultural e política, no contexto brasileiro, foram relidas, reinterpretadas e re-encenadas por todos os cineastas que sentiram um compromisso com a problemática diaspórica. A realidade diaspórica passa por diversos processos de mise en scène da cultura popular protagonizada pelas próprias populações afrodescendentes ${ }^{26}$; processos em que Paul Gilroy (2007) situa parte da modernidade das populações do Atlântico Negro. Por outro lado, cabe salientar que as narrativas de alguns documentários e filmes de ficção mostraram também que a "condição diaspórica" no Brasil engloba a Negritude e a Africanidade, mas sem forçosamente se reduzir a elas $^{27}$. O uso cada vez mais generalizado e aceito do termo de afrodescendência é sintomático dessa tomada de consciência de que a temática negra, tal como abordada no cinema, vai além de uma questão meramente biológica ou racial. A responsabilidade e o compromisso de todo e qualquer curtametragista tem mais a ver com as preocupações com os modos de representação dessa realidade diaspórica em toda a sua complexidade. A questão da legitimidade do autor da representação fílmica deixa de ser colocada apenas em termos étnico-raciais ("filmes de assunto negro" vs "filmes de cineastas negros"). Sendo assim, propomos a noção de "filme diaspórico" (no lugar de "filme de assunto negro" ou de "cinema diaspórico"), pois ela nos afasta da metafísica da "raça" e da negritude. Na perspectiva da relação do cinema com a história e a memória, podemos aferir que qualquer obra tem um compromisso com a problemática diaspórica, independentemente dos sentimentos de pertencimento étnico-racial que o

26 Os processos de "crioulização", de "miscigenação", de interculturalidade e de multiculturalismo na "Neo-América" tais como definidos por Glissant (2007) e outros autores.

27 Não há como negar que, durante muito tempo, as lutas para uma afirmação política dos negros exploraram exaustiva e estrategicamente essas duas dimensões da condição diaspórica.

74 Número temático: Literatura, cultura e memória negra. A Cor das Letras - UEFS, n. 12, 2011 
diretor teria ou não com uma comunidade diaspórica em questão. Nesse caso, o compromisso do cineasta com a representação da problemática diaspórica bastaria para situá-lo no processo de discursividade que o leva à realização de um "filme diaspórico". Com o mesmo "filme diaspórico", o cineasta em questão estaria também cumprindo um "dever de memória" no contexto de um país que tem sua história e seu presente marcados pelos traços e vestígios da escravidão. Em outras palavras, não há, a priori, uma relação de homologia étnico-racial entre o cinema e a problemática diaspórica a ponto de "predestinar" alguns cineastas para essa temática. A noção de "filme diaspórico" nos permite não só introduzir um primeiro princípio de organização no conjunto de filmes (de longa ou curta-metragem) realizados sobre a memória e as diversas facetas da realidade das populações afrodescendentes bem como pode servir de "conceito" operatório para a definição de um campo discursivo particular dentro do cinema brasileiro em que se encontram, além dos filmes feitos, diretores afrodescendentes, obras de outros cineastas brasileiros "brancos" ou não "negros". A partir da categoria discursiva genérica de "filmes diaspóricos", inclusive fica compreensível a ideia de Mostras Temáticas ("Da Atlântida à Feijoada" - SP, "Mostra de Cinema Negro e das Diásporas" - RJ) e do portal Curtadoc de constituir um acervo fílmico bem eclético e heterogêneo em torno do tema dos afrodescendentes. Afinal, todos os cineastas manifestam, de uma forma ou de outra, um compromisso ético quando fazem da "condição diaspórica" um objeto de representação e um objeto do discurso de seu documentário no contexto brasileiro. Essa polifonia no campo do cinema de curta-metragem se acompanha de uma multiplicação de sujeitos de discursos, todos mais ou menos qualificados para representar a mesma realidade.

\section{CONCLUSÃO}

No final, se existe de fato um campo discursivo dos minidocumentários brasileiros contemporâneos sobre a "condição diaspórica", ele toma forma através das diversas relações táticas e estratégicas que cada curta ou média-metragem mantém com um determinado aspecto da realidade, da memória das populações afrodescendentes. Constatamos que as preocupações em representar os "assuntos negros" resultam paulatinamente em projetos fílmicos de viés mais ensaístico na abordagem de vários aspectos ligados à própria "condição diaspórica". Mesmo reconhecendo o valor de cada filme isolado nesse debate, preferimos focar nossa análise na obra e nos percursos dos diretores que vêm se consagrando de certa ma- 
neira junto à crítica pela forma de militantismo político e estético lúcido que manifestam nos seus filmes e nos seus manifestos e declarações prosaicas. Nossa intenção era partir dos trabalhos desses diretores-autores para tirar dados que pudessem servir de hipóteses na definição dos novos rumos do cinema negro ou diaspórico no Brasil.

\section{REFERÊNCIAS}

ARAÚJO, Joel Zito (de). A negação do Negro: o negro na telenovela brasileira. São Paulo Ed. SENAC, 2004.

BERNARDET, Jean-Claude. Cineastas e imagens do povo. São Paulo: Cia. das Letras, 2003.

BLUHER, Dominique; PILARD, Philippe. (Org.). Le court métrage documentaire français de 1945 à 1968: créations et créateurs. Paris: Ed. PUR, 2009.

CARVALHO, Noel. Racismo e anti-racismo no Cinema Novo. In: HAMBÚRGUER, Esther; AMÂNCIO, Tunico et al. Estudo de Cinema, Socine. São Paulo: Annablume, 2008, p. 53-60.

CÉSAIRE, Aimé. Discours sur le colonialisme. Suivi de Discours sur la Négritude. Paris: Présence Africaine, 2004

CHIVALLON, Christine; BERTHOMIÈRE, William: Les diásporas dans Le monde contemporain. Paris: Karthala - MSHA, 2006.

DE, Jeferson. Dogma feijoada: o cinema negro brasileiro. São Paulo: Ed. Imprensa Oficial, 2005.

DIAWAR, M. (Org.). Black American cinema. New York: Routledge, 1993,

EYENE, Christine. Nouvelle topographie d'un Atlantique noir. [Entrevista com Paul Gilroy], Africultures (Diaspora: identité plurielle), n. 72, p. 82-87, 2007.

FOUCAULT, Michel. L'archéologie du savoir. Paris: Gallimard, 1969.

FOUCAULT, Michel. Estética: literatura e pintura, música e cinema. Org. e sel. de textos: Manoel Barros da Motta. Trad. Inês Autan Dourado Barbosa. 2. ed. Rio de Janeiro: Forense Universitária, 2009.

GILROY, Paul. Entre campos: nações, culturas e o fascínio da raça. Trad. Célia M.M de Azevedo et al. São Paulo: Annablume, 2007, p. 151

GLISSANT, Edouard. Introdução a uma poética da diversidade. Trad. Enilce Albergaria Rocha. Juiz de Fora: Ed. UFJF, 2005.

HALL, Stuart. Da Diáspora: identidades e mediações Culturais. Trad. e org. Adelaine Guardiar, Liv Sovik. Belo Horizonte: Editora UFMG, 2003.

LE GOFF, Jacques, Histoire et mémoire. 2. ed. Paris: Gallimard, 1988, p. 111.

NAFICY, Hamid. An accented cinema: exilic and diasporic filmmaking. 1. ed. New Jersey: Princeton University Press, 2001.

NAFICY, Hamid. Situating Accented cinema. In: EZRA, E. (Org.). Transnational cinema, the filme reader. New York: Routlege, 2006, p. 111-129. 
NEVES, David. O cinema de assunto e autor negros no Brasil. Cadernos Brasileiros: 80 anos de abolição. Rio de Janeiro, ano 10, n. 47, 1968, p. 75-81

RATTS, Alex. Eu sou Atlântica: sobre a trajetória de vida de Beatriz Nascimento. São Paulo: Editora Imprensa Oficial do Estado de São Paulo e Instituto Kuanza, 2009.

RODRIGUES, João Carlos. O Negro Brasileiro e o Cinema. Rio de Janeiro: Pallas, 2001.

VANOYE, Francis; GOLIOT-LÉTÉ, Anne. Ensaio sobre a análise fílmica. São Paulo: Papirus. 
